\title{
Improvement of Mathematical Learning Activities And Results Through PBL and Congretting Media in Class $1^{\text {st }}$ Students
}

\author{
Siti Aminah \\ SDN Pende 02 \\ sitiaminah@gmail.com
}

\section{Article History}

accepted $14 / 11 / 2020$

approved $21 / 11 / 2020$

published 26/11/2020

\begin{abstract}
The researchers made improvements by applying a scientific approach with the Problem Based Learning model and concrete media. This type of research is classroom action research. which consists of two cycles, each cycle carried out with one meeting. Each cycle consists of the planning, action, observation and reflection stages. The research subjects were grade I students of SDN Pende 02. The data collection techniques used test and non-test techniques obtained from observations and documentation. The results of this study are the use of concrete media and problem based learning can improve student learning outcomes on the subject of addition and subtraction of numbers in grade I SDN Pende 02, Kersana District, Brebes Regency. In the first cycle of students who completed there were 14 students, the percentage of classical student learning completeness was $63.63 \%$. In cycle II students who completed an increase of 20 students, students' reading completeness was $90.90 \%$. So it can be concluded that student learning outcomes have increased and are said to be complete.
\end{abstract}

Keywords: Learning outcomes, mathematics, concrete media, scientific approach, PBL

\begin{abstract}
Abstrak
Peneliti mengadakan perbaikan dengan menerapkan pendekatan saintifik dengan model Problem Based Learning dan media konkret. Jenis penelitian yang digunakan adalah penelitian tindakan kelas. yang terdiri atas dua siklus, masing-masing siklus dilaksanakan dengan satu kali pertemuan. Setiap siklus terdiri atas tahap perencanaan, pelaksanaan tindakan, observasi dan refleksi. Subjek penelitian adalah siswa kelas I SDN Pende 02. Teknik pengumpulan data menggunakan teknik tes dan nontes yang diperoleh dari hasil observasi dan dokumentasi. Hasil dari penelitian ini adalah Penggunaan media kongkrit dan problem based learning dapat meningkatkan hasil belajar siswa pada pokok bahasan penjumlahan dan pengurangan bilangan pada siswa kelas I SDN Pende 02 Kecamatan Kersana Kabupaten Brebes. Pada siklus I siswa yang tuntas ada 14 siswa, persentase ketuntasan belajar siswa secara klasikal 63,63\%. Pada siklus II siswa yang tuntas mengalami peningkatan 20 siswa, ketuntasan membaca siswa adalah $90,90 \%$. Sehingga dapat disimpulakn bahwa hasil belajar siswa mengalami peningkatan dan dikatakan tuntas.
\end{abstract}

Kata kunci: Hasil belajar, matematika, media kongkrit, pendekatan saintifik, dan PBL

Social, Humanities, and Education Studies (SHEs): Conference Series https://jurnal.uns.ac.id/shes

p-ISSN 2620-9284

e-ISSN 2620-9292 


\section{PENDAHULUAN}

Dari beberapa mata pelajaran yang di sajikan pada Sekolah Dasar, matematika adalah salah satu mata pelajaran yang menjadi kebutuhan sistem dalam melatih penalarannya. Melalui pengajaran matematika diharapkan akan menambah kemampuan, mengembangkan ketrampilan dan aplikasinya. Selain itu, matematika merupakan sarana berpikir dalam menentukan dan mengembangkan ilmu pengetahuan dan teknologi, bahkan matematika merupakan metode berpikir logis, sistematis dan konsisten. Oleh karena itu semua masalah kehidupan yang membutuhkan pemecahan secara cermat dan teliti selalu harus berpaling pada matematika.

Matematika merupakan ilmu yang mendasari perkembangan teknologi modern. Selain itu, matematika merupakan sarana berpikir dalam menentukan sekaligus mengembangkan ilmu pengetahuan dan teknologi, mempunyai peran penting dalam berbagai macam disiplin, dan dapat memajukan daya pikir manusia. Untuk mencipta dan menguasai teknologi dimasa depan, diperlukan penguasaan matematika yang kuat sedini mungkin

Pembelajaran Matematika masih menjadi masalah bagi siswa. Hal ini dapat dilihat dari nilai rata-rata kelas untuk bidang studi Matematika lebih rendah daripada niai rata-rata kelas untuk bidang studi yang lain. dari 22 anak yang ada, baru 8 anak atau $36,36 \%$ yang mencapai ketuntasan belajar, sedangkan 14 anak atau 63,63\% belum mencapai ketuntasan belajar Matematika, khususnya pada materi penjumlahan dan pengurangan.

Selama ini pembelajaran Matematika hanya dijadikan tempat mengaplikasikan konsep. Di sekolah, dalam pembelajaran Matematika, siswa hanya diajarkan teori/definisi/teorema, kemudian diberikan contoh-contoh, dan selanjutnya diberikan soal latihan, sehingga pengertian siswa tentang konsep sangat lemah dan seringkali siswa mengalami kesulitan Matematika di kelas. Selain itu, urutan pembelajaran seperti diatas dirasa kurang sesuai dengan perkembangan intelektual siswa, karena pada umumnya perkembangan intelektual siswa berkembang dari konkret ke abstrak (Soedjadi, 2001: 1).

Menurut Sudjana (2010: 22), hasil belajar adalah kemampuan yang dimiliki siswa setelah menerima pengalaman belajar. Banyak sekali faktor yang menjadi penyebab rendah hasil belajar peserta didik terhadap pelajaran Matematika. yang mempengaruhi hasil belajar (Rusman, 2012:124) antara lain meliputi faktor internal dan faktor eksternal, salah satunya adalah pemilihan media dan metode yang sesuai.

Untuk materi penjumlahan dan pengurangan bilangan pada siswa kelas 1 media yang sesuai adalah media benda kongkrit dan metode PBL. Pembelajaran menggunakan media benda konkrit lebih mampu memberikan pengalaman riil kepada siswa karena siswa dapat melihat, merasakan dan meraba alat peraga yang digunakan guru. Pengalaman belajar yang lebih konkrit akan lebih tepat bagi anak usia sekolah dasar.

Model Problem Based Learning (PBL) adalah model pembelajaran dengan pendekatan pembelajaran siswa pada masalah autentik sehingga siswa mau bertanya, siswa aktif, dan tidak merasa bosan. Prinsip utama PBL adalah penggunaan masalah nyata sebagai sarana bagi peserta didik untuk mengembangkan pengetahuan dan sekaligus mengembangkan kemampuan berpikir kritis dan kemampuan pemecahan masalah (Hosnan, 2014:300).

Berdasarkan latar belakang di atas, maka rumusan masalah dalam penelitian ini adalah: (1) Bagaimanakah pendekatan saintifik dengan model PBL dan media konkret dapat meningkatkan aktivitas siswa dalam pembelajaran matematika pokok bahasan penjumlahan dan pengurangan bilangan pada siswa kelas I SDN Pende 02 kecamatan Kersana Kabupaten Brebes?, (2) Apakah pendekatan saintifik dengan model PBL dan media konkret dapat meningkatkan hasil belajar siswa dalam 
pembelajaran matematika pokok bahasan penjumlahan dan pengurangan bilangan pada siswa kelas I SDN Pende 02 kecamatan Kersana Kabupaten Brebes?, Tujuan dari penelitian ini adalah untuk (1) Mendeskripsikan peningkatan aktivitas siswa dalam pembelajaran Matematika dengan menggunakan pendekatan saintifik dengan model PBL dan media konkret. Meningkatkan hasil belajar siswa dalam pembelajaran matematika dengan menggunakan pendekatan saintifik dengan model PBL dan media konkret. Hipotesis masalah dalam penelitian ini adalah jika guru menggunakan media kongkrit dan pendekatan Saintifik dengan model PBL pada pelajaran matematika pokok bahasan penjumlahan dan pengurangan bilangan pada siswa kelas I SDN Pende 02 Kecamatan Kersana Kabupaten Brebes, maka aktivitas dan hasil belajar siswa akan meningkat.

\section{METODE}

Menurut Arikunto (2006:128) subjek dalam penelitian adalah subjek dari mana data diperoleh. Subjek dalam penelitian ini adalah siswa kelas I semester ganjil di SDN Pende 02 Kecamatan Kersana Kabupaten Brebes. Jumlah siswa kelas I adalah 22 siswa, siswa laki laki berjumlah 6 dan siswa perempuan 16, mata pelajaran yang diteliti matematika.

Pendekatan penelitian yang digunakan adalah pendekatan penelitian kualitatif. Penelitian kualitatif adalah penelitian yang mengungkapkan gejala secara holistik kontekstual melalui pengumpulan data dan latar alami dengan memanfaatkan dari peneliti sebagai instrumen kunci (Sunardi, 2009:1). Jenis penelitian yang digunakan adalah penelitian tindakan kelas. Penelitian tindakan kelas adalah penelitian tindakan yang dilakukan di kelas yang menyangkut masalah-masalah kelas (interaksi guru dan siswa), dan masalah pendidikan serta pembelajaran (Hobri, 2007:1).

Salah satu model pembelajaran inovatif yang melibatkan siswa secara aktif dalam pembelajaran adalah model Problem Based Learning (PBL). Melalui model Problem Based Learning, masalah dunia nyata dijadikan sebagai awal pembelajaran di mana siswa menyelesaikan masalah dengan kolaboratif, komunikatif dan kooperatif dengan bekerja dalam kelompok sedangkan guru bertugas sebagai fasilitator dalam pembelajaran. Selain itu, siswa dapat menyelesaikan masalah matematika yang sesuai dunia nyata yang mendorong siswa untuk memberi alasan, berpikir kritis dan mempertimbangkan bukti-bukti, mencari dan berbagi informasi yang relevan. Diharapkan dengan penerapan model Problem Based Learning dalam pembelajaran matematika dapat meningkatkan aktivitas siswa dan hasil belajar siswa dalam pembelajaran matematika, sehingga berdampak pada hasil belajar matematika yang meningkat,

Model skema yang digunakan dalam penelitian ini adalah model Hopkins yaitu model skema yang menggunakan prosedur kerja yang dipandang sebagai siklus spiral yang terdiri dari perencanaan, tindakan, observasi, dan refleksi yang kemudian diikuti siklus berikutnya. Penelitian ini menggunakan dua siklus yang mencakup empat tahapan tersebut diatas. Penelitian ini dilaksanakan dalam 2 siklus pembelajaran. Tindakan pendahuluan dalam penelitian ini adalah mengadakan tes pendahuluan untuk mengetahui hasil belajar siswa. Setelah dilaksanakannya pembelajaran menggunakan media kongkrit, siswa diberi tes akhir I untuk mengetahui ketuntasan hasil belajar siswa dan digunakan sebagai acuan perbaikan untuk melaksanakan siklus II. Setelah dilaksanakan siklus II, siswa diberi tes Akhir II untuk mengetahui ketuntasan hasil belajar siswa dan akan dijadikan perbandingan antara siklus I dan siklus II.

Metode pengumpulan data adalah cara yang dapat digunakan peneliti untuk mengumpukan data (Arikunto, 2002:126). Metode yang digunakan untuk mengumpulkan data dalam penelitian ini adalah metode observasi, metode wawancara, metode tes, dan metode dokumentasi. Observasi yang digunakan dalam penelitian ini adalah observasi langsung yaitu observasi yang dilakukan terhadap 
gejala atau proses yang terjadi dalam situasi nyata dalam pembelajaran. Tes merupakan serentetan pertanyaan atau latihan yang digunakan untuk mengukur keterampilan, pengetahuan, intelegensi, kemampuan, dan akal yang dimiliki oleh individu atau kelompok (Arikunto, 2006:174). Jenis wawancara yang digunakan dalam penelitian ini adalah wawancara bebas terpimpin yang nantinya pertanyaan sudah dipersiapkan oleh peneliti dan responden bebas menjawab sesuai dengan pertanyaan tersebut.

Untuk menghitung ketuntasan hasil belajar siswa setelah penerapan media kongkrit dan PBL dapat dilakukan dengan membagi jumlah siswa yang tuntas belajar dengan jumlah seluruh siswa. Ketuntasan perorangan, seorang siswa dikatakan tuntas apabila telah mencapai nilai $\geq 65$ dari nilai maksimal 100. Ketuntasan klasikal suatu kelas dikatakan tuntas apabila terdapat minimal $70 \%$ yang telah mencapai nilai $\geq 65$ dari nilai maksimal 100. Jika pada siklus pertama mencaai ketuntasan klaksikal, maka tidak perlu dilaksanakan siklus yang kedua.

\section{HASIL DAN PEMBAHASAN}

Data penelitian yang diperoleh berupa data observasi berupa pengamatan pengelolaan belajar aktif dan pengamatan aktivitas siswa dan guru pada akhir pembelajaran, dan data tes formatif siswa pada setiap siklus. Hasil tes formatif digunakan untuk mengukur tingkat keberhasilan penelitian.

Penelitian tindakan kelas ini dilakukan dalam dua siklus, dimana tiap siklusnya terdiri dari satu tindakan yang diwujudkan dalam satu kali pertemuan pembelajaran yang lamanya 2 x 35 menit. Subjek dalam penelitian ini adalah siswa kelas I semester ganjil di SDN Pende 02 Kecamatan Kersana Kabupaten Brebes. Jumlah siswa kelas I adalah 22 siswa, siswa laki laki berjumlah 6 dan siswa perempuan 16, mata pelajaran yang diteliti matematika. Jadi pada penelitian tindakan kelas ini diadakan proses pembelajaran sebanyak dua pertemuan. Pelaksanaan kegiatan belajar mengajar untuk siklus I di Kelas 1 dengan jumlah siswa 22 siswa. Pada tahap perencanaan peneliti mempersiapkan perangkat pembelajaran yang terdiri dari rencana pelajaran Siklus 1, LKPD 1, soal tes formatif 1 dan media kongkrit yang berupa buah jeruk dan apel. Proses belajar mengajar mengacu pada rencana pelajaran yang telah dipersiapkan. Proses belajar mengajar berjalan dengan lancar meskipun pada awal pembelajaran masih terdapat beberapa siswa yang gaduh dan berbicara sendiri. Disaat menerangkan penjumlahan dan pengurangan menggunakan media yang disediakan siswa mulai antusias mendengarkan materi yang diajarkan. Pembelajaran menggunakan media kongkrit membuat konsentrasi dan semangat belajar siswa meningkat. Guru menerangkan pembelajaran menggunakan media kongkrit berupa buah jeruk dan apel. Guru menyediakan 2 buah jeruk dan 2 buah apel kemudian kedua buah tersebut ditambahkan dengan cara menghitung kedua buah tersebut satu persatu. Setelah selesai menerangkan pembelajaran penjumlahan dan pengurangan siswa diberi kesempatan untuk mencoba menggunakan media menghitung penjumlahan dan pengurangan di depan kelas. Karena media yang digunakan tidak menjangkau semua siswa akhirnya kelas mulai gaduh kembali. Tetapi masih bisa diatasi oleh guru.

Pada tahap selanjutnya siswa diberi lembar kerja siswa tentang penjumlahan dan pengurangan bilangan menggunakan media kongkrit. Karena media yang tersedia terbatas maka siswa di kelompokkan menjadi beberapa kelompok. Dalam mengerjakan dengan kelompoknya, siswa terlihat belum terbiasa dengan situasi tersebut dan berusaha memecahkan masalah dengan menggunakan media secara berebutan, interaksi antar siswa dalam kelompok belum terlihat, ada beberapa siswa yang masih tidak mau mengerjakan dan menggunakan alat peraga secara berkelompok dan cenderung ramai sendiri. Guru berkeliling melakukan bimbingan 
kepada kelompok yang membutuhkan penjelasan dan terus memotivasi siswa supaya saling bekerjasama untuk membantu teman sekelompoknya. Pada saat proses pembelajaran berlangsung, teman sejawat melakukan observasi terhadap aktifitas siswa dan melakukan observasi terhadap guru (peneliti) dalam melakukan pembelajaran.

Pada umumnya dapat dikatakan bahwa, selama proses pembelajaran berlangsung siswa terlihat senang dan tertarik terhadap pembelajaran karena terdapat alat peraga yang akan digunakan dalam pembelajaran. Hal ini dapat terlihat dari antusias siswa dalam menyelesaikan soal-soal menggunakan alat peraga.

Berdasarkan analisis terhadap tes akhir siklus I, dapat disimpulkan bahwa penggunaan media kongkrit untuk meningkatkan hasil belajar siswa belum tuntas. Hal ini dapat dilihat dari persentase ketuntasan belajar siswa secara klasikal 63,63\% Terbukti bahwa daya serap siswa secara klasikal belum tuntas belajarnya karena mencapai $\leq 65 \%$ dari jumlah siswa seluruhnya. Sedangkan hasil observasi terhadap aktifitas siswa selama pembelajaran menggunakan media kongkrit berlangsung pada siklus I yaitu, menjawab pertanyaan dari guru 65,63\%, menggunakan alat peraga $78,13 \%$, dan presentasi $62,5 \%$, Persentase rata-rata aktifitas siswa dalam menggunakan media kongkrit secara keseluruhan pada siklus I mencapai 68,75\%. Dari data diatas dapat dibuat grafik aktifitas belajar sebagai berikut:

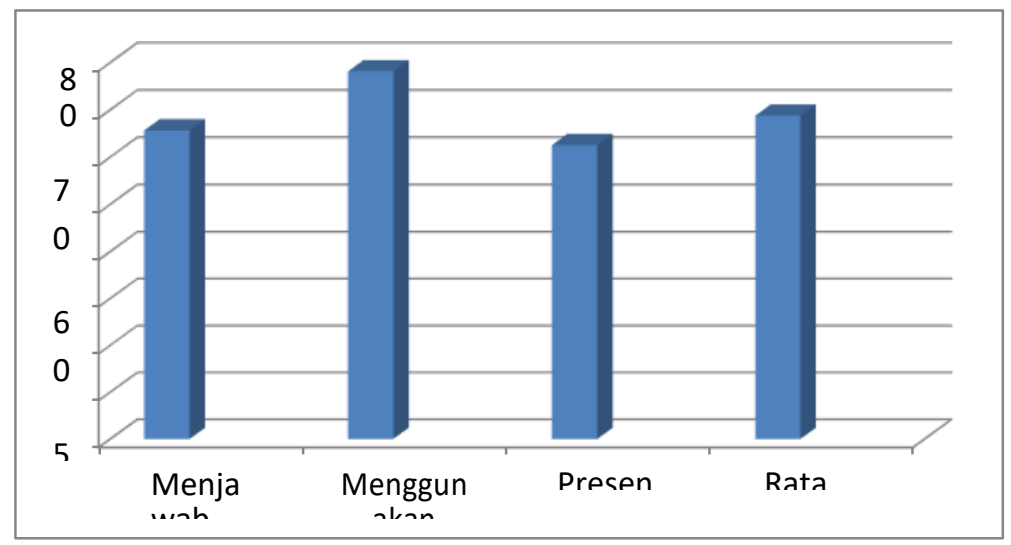

Gambar 1. Grafik Aktivitas Siklus I

Karena hasil tes akhir siklus I belum tuntas dan aktifitas siswa belum maksimal, maka perlu dikaji ulang dan diadakan pembenahan dalam RPP dan juga strategi/manajemen kelas pada pertemuan berikutnya yaitu pada siklus yang kedua. Diharapkan setelah siklus kedua berlangsung nilai tes akhir siswa dapat meningkat, begitu juga dengan aktifitas siswa dalam pembelajaran pada pokok bahasan penjumlahan dan penguranagn bilangan.

Pembelajaran pada siklus II lebih baik dari pada pembelajaran pada siklus I, Pada tahap ini, dilakukan beberapa kegiatan yang meliputi penyusunan Rencana Pelaksanaan Pembelajaran (RPP), lembar kerja siswa, lembar observasi siswa dan guru. Sebelum pembelajaran dimulai, peneliti menjelaskan kembali sekilas tentang proses pembelajaran menggunakan media kongkrit. Pada awal kegiatan peneliti menyampaikan atau menginformasikan materi yaitu penjumlahan dan penguranagn bilangan, kemudian guru memotivasi siswa agar lebih giat dalam belajar. Proses selanjutnya guru menyampaikan materi menggunakan media kongkrit seperti siklus pertama tetapi memberi sedikit penguatan. Setelah materi diberikan beberapa siswa maju kedepan mengerjakan cotoh soal yang diberikan guru menggunakan media kongkrit, siswa sangat antusias menggunakan media tersebut. Setelah selesai latihan soal siswa mengerjakan LKPD, dalam proses pengerjaan soal, siswa terlihat sudah terbiasa dan lebih baik dalam proses pengerjaan soal dari pada pertemuan 
sebelumnya. Siswa sudah banyak yang mengerti akan cara pengerjaannya. Namun demikian, masih terdapat siswa yang masih membuat kegaduhan dengan mengganggu teman sebangkunya dan guru langsung menegur untuk tidak mengganggu temannya.

Kegiatan observasi dilakukan untuk mengamati seluruh kegiatan yang terjadi dan aktifitas siswa selama proses pembelajaran menggunakan media kongkrit. Selama pembelajaran berlangsung, secara keseluruhan siswa lebih siap dan antusias dibandingkan sebelumnya. Siswa lebih semangat dalam menyelesaikan soal, berinteraksi dengan guru dan siswa lainnya, bertanya apabila ada kesulitan pada saat mengerjakan atau pada saat guru sedang memberikan informasi tentang materi.

Berdasarkan analisis terhadap tes akhir siklus II, dapat disimpulkan bahwa penggunaan media kongkrit untuk meningkatkan hasil belajar siswa sudah tuntas. Hal ini dapat dilihat dari persentase ketuntasan belajar siswa secara klasikal 87,5\% Terbukti bahwa daya serap siswa secara klasikal belum tuntas belajarnya karena mencapai $\geq 65 \%$ dari jumlah siswa seluruhnya. Sedangkan hasil observasi terhadap aktifitas siswa selama pembelajaran menggunakan media kongkrit berlangsung pada siklus II yaitu, menjawab pertanyaan dari guru $81,25 \%$, menggunakan alat peraga $100 \%$, dan presentasi $90,63 \%$, Persentase rata-rata aktifitas siswa dalam menggunakan media kongkrit secara keseluruhan pada siklus II mencapai 90,63\%. Dari data diatas dapat dibuat tabel ketuntasan belajar sebagai berikut

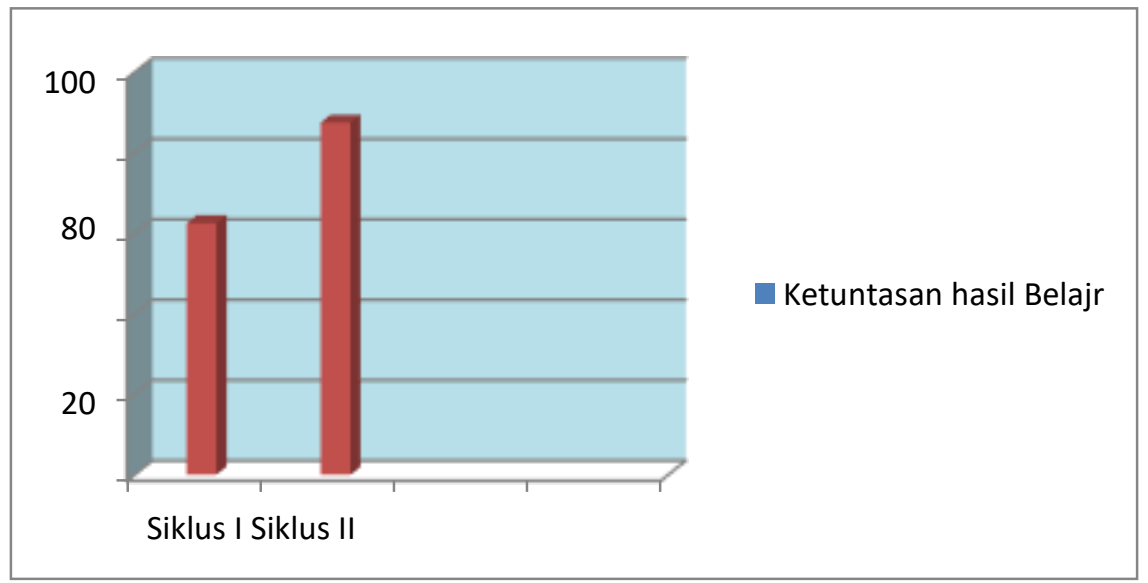

Gambar 2. Grafik Ketuntasan Hasil Belajar

Hasil dari penelitian ini menunjukkan bahwa penggunaan media kongkrit pada mata pelajaran matematika terbukti dapat meningkatkan hasil belajar dan aktivitas siswa kelas I SDN Pende 02 kecamatan Kersana Kabupaten Brebes

\section{SIMPULAN}

Berdasarkan hasil penelitian dan pembahasan yang telah diuraikan, maka dapat disimpulkan sebagai berikut:

1. penggunaan media kongkrit dan PBL pada pelajaran matematika pokok bahasan penjumlahan dan pengurangan bilangan pada siswa kelas I SDN Pende 02 kecamatan Kersana Kabupaten Brebes berjalan dengan baik, siswa terlihat lebih tertarik dalam mengikuti pelajaran. Meskipun dalam pelaksanaannya masih terdapat siswa yang membuat gaduh, siswa sudah mulai tenang setelah disajikan beberapa media kongkrit. 2. Melalui penerapan model Problem Based Learning dan media konkret dapat meningkatkan aktivitas siswa pada pokok bahasan penjumlahan dan pengurangan bilangan pada siswa kelas I SDN Pende 02 Kecamatan Kersana Kabupaten Brebes. Pada siklus I menjawab pertanyaan dari guru $65,63 \%$, menggunakan alat peraga 
$78,13 \%$, dan presentasi $62,5 \%$, Persentase rata-rata aktifitas siswa dalam menggunakan media kongkrit secara keseluruhan pada siklus I mencapai 68,75\%. Pada siklus II menjawab pertanyaan dari guru $81,25 \%$, menggunakan alat peraga $100 \%$, dan presentasi $90,63 \%$, Persentase rata-rata aktifitas siswa dalam menggunakan media kongkrit secara keseluruhan pada siklus I mencapai 90,63\%. Sehingga dapat disimpulakn bahwa aktivitas siswa mengalami peningkatan.

3. Penggunaan media kongkrit dan PBL dapat meningkatkan hasil belajar siswa pada pokok bahasan penjumlahan dan pengurangan bilangan pada siswa kelas I SDN Pende 02 Kecamatan Kersana Kabupaten Brebes. Pada siklus I siswa yang tuntas ada 14 siswa, persentase ketuntasan belajar siswa secara klasikal 62,5\%. Pada siklus II siswa yang tuntas mengalami peningkatan 20 siswa, ketuntasan belajar siswa adalah $90,63 \%$. Sehingga dapat disimpulakn bahwa hasil belajar siswa mengalami peningkatan dan dikatakan tuntas

Berdasarkan hasil penelitian tentang penggunaan media kongkrit untuk meningkatkan hasil belajar pokok bahasan penjumlahan dan pengurangan bilangan pada siswa pada siswa kelas I SDN Pende 02 Kecamatan Kersana Kabupaten Brebes maka saran yang diberikan adalah:

1. Dengan melihat adanya peningkatan aktifitas siswa dalam kegiatan pembelajaran, hasil belajar siswa, maka diharapkan guru dapat menggunakan media kongkrit dan metode PBL dalam proses pembelajaran matematika.

2. Berdasarkan hasil temuan penelitian masih ditemukan beberapa hambatan, maka bagi siswa yang mengalami kesulitan hendaknya diberikan suatu bimbingan secara individu agar siswa lebih memahami permasalahan, merencanakan penyelesaian, selalu siap dalam menerima materi pembelajaran, mengingat materi yang telah diberikan dengan cara sering mengerjakan soal-soal latihan, serta membiasakan mengerjakan soal menggunakan media kongkrit.

\section{DAFTAR PUSTAKA}

Aisyah, Nyimas, dkk. 2008. Pengembangan Pembelajaran Matematika SD. Jakarta: Direktorat Jenderal Pendidikan Tinggi Departemen Pendidikan Nasional.

B. Etherington. Matthew. 2011. Investigative Primary Science: A Problem-based

Arikunto, S. 2006. Prosedur Penelitian Suatu Pendekatan Praktek revisi VI. Jakarta: Rineka Cipta

Arikunto, S. 2006. Prosedur Penelitian Suatu Pendekatan Praktek revisi V. Jakarta: Rineka Cipta

Hamiyah, Nur dan Muhammad Jauhar. 2014. Strategi Belajar-Mengajar Di Kelas. Jakarta: Prestasi Pustakaraya.

Hayyu Nur Fadlillah. 2012. Penggunaan Media Konkret Meningkatkan Aktivitas Siswa Matematika Kelas I SDN 07 Sungai Soga Bengkayang. Jurnal Penelitia PendidikanVol 1 No 1: Hal 33-36. PGSD, FKIP Universitas Tanjungpura, Pontianak

Hobri. 2007. Penelitian Tindakan Kelas untuk guru dan praktisi. Jember: Pena Salsabila Rusman. 2012. Model Mmodel Pembelajaran. Depok: PT Raja Grafindo Persada Soedjadi. 2000. Kiat Pendidikan Matematika di Indonesia. Dirjen Dikti. Jakarta:Dekdikbut

Learning Approach. Australian Journal of Teacher Education vol 36 No 9: Hal 36-40. Trinity Western University

Sudjana, Nana. 2010. Penilaian Hasil Proses Belajar Mengajar. Bandung: PT Remaja Rosdakarya 